\title{
Pengaruh Akupresur Stroke 14 Titik Terhadap Rentang Gerak Ekstremitas Atas Dan Bawah Pada Pasien Stroke Non Hemoragik
}

\author{
Lalu Hersika Asmawariza a, Reza Indra Wiguna ${ }^{a}$ \\ ${ }^{a}$ Program Studi S1 Keperawatan, Fakultas Kesehatan, Universitas Qamarul Huda Badaruddin \\ Email Korespondensi: laluhersikariza@gmail.com
}

\begin{abstract}
Introduction: Decreased limb function is one of the complications that often occurs in non-hemorrhagic stroke patients who experience hemiparesis as a result of limited joint motion in the upper and lower extremities. Acupressure is useful in improving extremity function by increasing the movement of qi (vital energy) flow in the body, but acupressure has never been done by nurses in hospital care rooms as a therapy to prevent and overcome motor function complications in non-hemorrhagic stroke patients. This study aims to identify the effect of acupressure at 14 points on the range of motion of the upper and lower extremities in non-hemorrhagic stroke patients. Method: This study used an experimental design with pre-post test approach design and a control group of 38 respondents ( $n$ control and $n$ intervention = 19). The intervention group was given 14-point stroke acupressure for 15 minutes once a day for 7 days. Results: The results showed that there were significance differences of range of motion of the upper and lower limbs between the intervention group and the control group $(p=0.000)$. Conclusion: Acupressure at 14 points is an effective intervention to increase the range of motion of the upper and lower extremities in non-hemorrhagic stroke patients who have hemiparesis. The recommendation in this study is that nurses in the stroke center should apply 14-point acupressure as one of the SOPs in the treatment of non-hemorrhagic stroke patients to improve the range of motion in the extremities.
\end{abstract}

Keywords: Acupressure, Hemiparesis, Extremity Range of Motion, Stroke.

\begin{abstract}
ABSTRAK
Pendahuluan: Penurunan fungsi ekstremitas merupakan salah satu komplikasi yang sering terjadi pada pasien stroke non hemoragik yang mengalami hemiparesis sebagai akibat dari keterbatasan rentang gerak sendi pada ekstremitas atas dan bawah. Akupresur bermanfaat dalam memperbaiki fungsi ekstremitas dengan melancarkan pergerakan aliran qi (energi vital) di dalam tubuh, tetapi akupresur belum pernah dilakukan oleh perawat di ruang perawatan rumah sakit sebagai salah satu terapi untuk mencegah dan mengatasi komplikasi fungsi motorik pada pasien stroke non hemoragik. Penelitian ini bertujuan untuk mengidentifikasi pengaruh akupresur pada 14 titik terhadap rentang gerak ekstremitas atas dan bawah pada pasien stroke non hemoragik. Metode: Penelitian ini menggunakan experimental design dengan pendekatan pre-post test design with control group pada 38 responden (n kontrol dan $n$ intervensi $=19$ ). Kelompok intervensi diberikan akupresur stroke 14 titik selama 15 menit sekali dalam sehari selama 7 hari. Hasil: Hasil penelitian menunjukkan adanya perbedaan yang bermakna pada rentang gerak ekstremitas atas dan bawah antara kelompok intervensi dan kelompok kontrol $(p=0,000)$. Kesimpulan: Akupresur pada 14 titik merupakan intervensi yang efektif untuk meningkatkan kemampuan rentang gerak ekstremitas atas dan bawah pada pasien stroke non hemoragik yang mengalami hemiparesis. Rekomendasi pada penelitian ini adalah perawat di ruang stroke senter bisa menerapkan akupresur 14 titik sebagai salah satu SOP dalam perawatan pasien stroke non hemoragik untuk meningkatkan kemampuan rentang gerak pada ekstremitas.
\end{abstract}

Kata kunci: Akupresur, Hemiparesis, Rentang Gerak Ekstremitas, Stroke. 
PROFESSIONAL HEALTH JOURNAL

Volume 2, No. 1, Desember 2020 (Hal. 51-63)

https://www.ojsstikesbanyuwangi.com/index.php/PHJ

\section{LATAR BELAKANG}

Stroke merupakan sindrom klinis yang awal timbulnya mendadak, progresif, berupa defisit neurologis fokal atau global yang berlangsung 24 jam atau lebih dan bisa menimbulkan kematian. Hal ini disebabkan oleh gangguan aliran darah otak nontraumatik. Stroke adalah penyakit neurologis terbanyak yang dapat mengakibatkan masalah kesehatan yang serius dan berdampak pada kecacatan, kematian, dan ekonomi keluarga, akibat dari adanya disfungsi motorik dan sensorik (Mansjoer A, 2000).

Manifestasi klinis stroke akut dapat berupa perubahan status mental, gangguan penglihatan, afasia, vertigo, mual-muntah, nyeri kepala dan penurunan fungsi motorik salah satunya ialah penurunan rentang gerak pada ekstremitas (Mansjoer A, 2010). Perubahan tersebut mempengaruhi struktur fisik maupun mentalnya (psikologi). Sehingga dengan adanya perubahan tersebut mobilisasi penderita stroke akut akan mengalami kemunduran aktivitas seperti kehilangan kekuatan otot, kelemahan menggerakkan kaki, kelemahan menggerakkan tangan, ketidakmampuan bicara, keterbatasan lapang pandang, ketidaksimetrisan pada wajah dan ketidakmampuan fungsi-fungsi motorik lainnya. Kondisi ini mengakibatkan terjadinya penurunan fungsi individu secara ekonomi dan sosial, karena stroke banyak terjadi pada usia produktif (Muttaqin A, 2011).

Pertolongan dan pengobatan pasien stroke tujuannya untuk meningkatkan aliran darah ke otak, mencegah kematian dan meminimalkan kecacatan yang ditimbulkan untuk penanganan pasien stroke yang akut pada terapi farmakologi biasanya diberikan microplasmin, dipasang infus untuk memasukkan cairan dan zat makanan, kemudian diberikan manitol atau kortikosteroid untuk mengurangi pembengkakan dan tekanan di dalam otak, akibat infiltrasi sel darah putih. Penderita stroke perlu penanganan yang baik untuk mencegah kecacatan fisik dan mental. Sebesar 30\% - 40\% penderita stroke dapat sembuh sempurna bila ditangani dalam waktu 6 jam pertama (golden periode), namun apabila dalam waktu tersebut pasien stroke tidak mendapatkan penanganan yang maksimal maka akan terjadi kecacatan atau kelemahan fisik dan penurunan kekuatan otot seperti hemiparese atau hemiplegi (Wiwit, 2010).

Asuhan keperawatan pada pasien stroke terbagi menjadi tiga fase yaitu fase akut, fase pasca akut, dan fase rehabilitasi. Pada fase akut tindakan medis dan keperawatan ditujukan untuk mempertahankan fungsi vital pada tubuh. Pada fase pasca akut tindakan keperawatan ditujukan untuk mempertahankan fungsi tubuh dan mencegah komplikasi. Salah satu program terapi non farmakologi yang diberikan pada pasien stroke pada fase pasca akut diruang perawatan untuk mengatasi gangguan pada motorik yaitu mobilisasi dini dan dengan latihan range of motion. Dan pada pasien stroke fase rehabilitasi pasca rawat inap perlu penanganan lebih lanjut untuk pemulihan motorik, dan meminimalkan angka kecacatan pada penderita stroke maka dapat dilakukan fisioterapi (Atika N, 2013).

Akupresur merupakan salah satu bentuk terapi holistik yang dapat memperbaiki perfusi jaringan yang dilakukan untuk memperbaiki fungsi motorik pada pasien stroke. Akupresur 
merupakan metode noninvasive yang prinsip kerjanya didasarkan pada prinsip akupuntur. Dalam ilmu pengobatan tradisional cina, akupresur telah digunakan untuk rehabilitasi ekstremitas atas pada pasien pasca stroke yang mengalami hemiplegia dan hemiparesis. Akupresur merupakan salah satu terapi tradisional cina yang didasarkan pada teori akupuntur meridian dengan teori Yin/Yang dalam ilmu filsafat timur (Black JM, 2009; LeMone P, 2008).

Adanya ujung- ujung saraf dan pembuluh darah yang banyak terdapat di sekitar titik- titik akupresur akan memperbesar respon. Sel mast melepaskan histamine, heparin, dab kinin protese yang menyebabkan vasodilatasi pada pembuluh darah. Histamin menyebabkan pelepasan nitric oxide dari endotel vaskuler yang merupakan mediator berbagai reaksi- reaksi kardiovaskuler, neurologis, imun, digestif dan reproduksi. Sel mast juga akan melepaskan platelet activating factor (PAF) yang kemudian di ikuti pelepasan serotonin dari platelet. Serotonin merangsang nosiseptor sendiri dan meningkatkan respon nosiseptor terhadap bradikinin. Bradikinin merupakan vasodilator kuat yang menyebabkan peningkatan permeabilitas vaskuler, hal ini menyebabkan terjadinya peningkatan sirkulasi darah kejaringan yang akan menyebabkan terjadinya perbaikan pada abnormalitas skeletal sehingga memperbaiki fungsi motorik pada ekstremitas (Saputra K, 2009; Si Q-m, 1998)

Shin dan Lee (2006) melaporkan hasil penelitiannya pada 30 pasien stroke pasca rawat inap yang mengalami nyeri bahu hemiplegik yang dibagi menjadi 15 pasien sebagai kontrol dan 15 pasien lainnya diberi intervensi akupresur 20 menit 2 kali dalam sehari selama 2 pekan, menunjukkan bahwa pemberian akupresur secara signifikan memperbaiki kekuatan otot ekstremitas atas $(\mathrm{P}<0,01)$ (Shin B-C, 2007) Penelitian lain yang telah dilakukan oleh Kang et al pada pasien stroke pasca rawat inap (2009), pada 56 sampel consecutive dibagi menjadi 2 kelompok (masing-masing 28 pasien untuk kelompok kontrol dan kelompok intervensi). Pada kelompok intervensi diberikan terapi akupresur setiap hari 10 menit selama 2 pekan (Kang HS, 2009). Hasil penelitian ini menunjukkan adanya perbedaan yang signifikan antara kelompok kontrol dan intervensi, dimana kelompok intervensi mengalami perbaikan ekstremitas atas dan aktivitas hidup sehari-hari dibandingkan dengan kelompok kontrol.

Hasil penelitian yang telah dilakukan oleh M. Adam (2011) pada 34 pasien stroke pasca rawat inap yang mengalami kelemahan otot dan rentang gerak ekstremitas atas, pada 34 sampel dibagi menjadi 2 kelompok (masing-masing 17 pasien untuk kelompok kontrol dan kelompok intervensi). Pada kelompok intervensi diberikan terapi akupresur setiap hari 10 menit selama 7 hari. Hasilnya menunjukkan adanya perbedaan yang signifikan antara kelompok kontrol dan intervensi, dimana kelompok intervensi mengalami perbaikan kekuatan otot dan rentang gerak ekstremitas atas dibandingkan dengan kelompok kontrol (Adam M, 2011)

Hasil penelitian lain yang telah dilakukan oleh Wayan Sukwana dkk (2013) pada 20 pasien stroke non hemoragik yang mengalami kelemahan otot ekstremitas atas, pada 20 sampel dibagi menjadi dua kelompok (masing-masing 10 pasien untuk kelompok kontrol dankelompok intervensi). Pada kelompok intervensi diberikan akupresur scapula pada titik GB 21, LI 15 dan TE 14 sekali sehari selama 1 bulan,hasilnya menunjukkan adanya perbedaan yang signifikan antara kelompok 
kontrol dan kelompok intervensi, dimana kelompok intervensi mengalami perbaikan kekuatan otot ekstremitas atas dibandingkan dengan kelompok kontrol (Sukwana IW, 2013).

Akupresur belum pernah dilakukan oleh perawat di ruang perawatan rumah sakit sebagai salah satu terapi untuk mencegah dan mengatasi komplikasi fungsi motorik pada pasien stroke. Akupresur adalah salah satu tindakan keperawatan yang dapat dilakukan oleh perawat dan merupakan salah satu intervensi yang tercantum dalam Nursing Intervention classifications (Butcher HK, 2007).

Dupler mengatakan akupresur merupakan suatu terapi yang efektif baik untuk pencegahan maupun pengobatan. Selain itu teknik akupresur mudah dipelajari dan diberikan dengan cepat, biayanya yang murah dan efektif untuk mengatasi berbagai gejala penyakit (Suharningsih, 1999) Oleh sebab tersebut peneliti tertarik untuk melakukan penelitian tentang pengaruh akupresur terhadap rentang gerak ekstremitas atas dan ekstremitas bawah.

\section{METODE PENELITIAN}

Jenis penelitian ini merupakan penelitian dengan jenis analitik komparatif berpasangan dengan menggunakan desain experimental with control group pretest posttest design, dan repeated measurement. Penelitian ini dilakukan di Rumah Sakit Umum Daerah Provinsi Nusa Tenggara Barat, Rumah Sakit Umum Daerah Kota Mataram, Rumah Sakit Umum Daerah Lombok Barat, Rumah Sakit Umum Daerah Lombok Tengah. Populasi dalam penelitian ini adalah semua pasien stroke non hemoragik yang dirawat di ruang stroke senter RSUD propinsi NTB, RSUD Kota Mataram, RSUD Lobar, RSUD Loteng. Teknik sampling pada penelitian ini menggunakan teknik stratified random sampling pada 38 orang, dari hasil perhitungan menggunakan teknik sampel diatas maka jumlah sampel pada penelitian ini 19 responden setiap kelompok.

Sampel yang dipilih pada penelitian ini adalah pasien stroke non hemoragik yang dirawat di ruang stroke senter RSUD propinsi NTB, RSUD Kota Mataram, RSUD Lobar, RSUD Loteng yang memenuhi kriteria inklusi dan eksklusi yang telah ditetapkan sebagai subjek penelitian.

Pemberian intervensi akupresur dilakukan oleh peneliti sendiri yang memiliki kompetesi melakukan akupresur setelah mengikuti pelatihan akupresur dan telah dinyatakan lulus dari Assosiasi Chiroprakter dan Akupresur Seluruh Indonesia (ACASI) yang bersertifikat.

Pada kelompok kontrol mendapatkan perawatan sesuai dengan SOP ruangan Stroke Center yaitu pemberian ROM, sedangkan kelompok perlakuan diberikan akupresur pada 14 titik yaitu LI 15 atau Jian Yu, SI 9 atau Jian Zhen, TE 14 atau Jian Liao, GB 21 atau Jian Jing, SI 11 atau Tian Zong, SI 12 atau Bing Feng, ST 36 atau Zusanli, GB 34 atau Yanghing Quan, ST 41 atau Jiexi, GB 39 atau Xuan Zhong, ST 31 atau Biguan, GB 30 atau Huan Tiao, SP 10 atau Xuchai, ST 34 atau Liang Qiu dilakukan selama 15 menit, sekali dalam sehari selama 7 hari dengan cara melakukan pemijatan menggunakan ibu jari tangan dengan menggunakan teknik sedasi yaitu memijat dengan gerakan memutar berlawanan dengan arah jarum jam.

Rentang gerak ekstremitas diukur dengan menggunakan alat goniometer yaitu 
sebuah alat untuk mengkaji rentang gerak sendi berupa busur derajat yang dilengkapi dengan sebuah lengan yang dapat digerakkan (movable arm) dan sebuah lengan yang tidak dapat digerakkan (fixed arm) sebagai axis. Pusat (titik nol) diletakkan pada sendi dimana bagian fixed arm goniometer diletakkan tegak lurus dengan sendi. Bersamaan dengan menggerakkan sendi bagian movable arm goniometer digerakkan untuk mengukur rentang gerak sendi dalam satuan derajat. Menurut Jong, Niewboer \& Aufdemkampe goniometer merupakan alat yang reliabel untuk mengukur rentang gerak sendi karena secara konsisten dapat menghasilkan nilai yang sama pada pengukuran berulang (Dupler, 2005).

\section{Ethical consideration}

Penelitian ini telah mendapatkan izin dari RSUD Propinsi NTB dengan nomor surat 070/3767/RSUDP/2016, RSUD Kota Mataram dengan nomor surat 445/3534/RSUD/XII/2016, RSUD Lombok Barat dengan nomor surat 800/2029/RSUD/XII/2016, RSUD Lombok Tengah dengan nomor surat 070/884/RSUD/XII/2016 yang menyatakan penelitian memenuhi syarat dan laik etik. Sebelum dilakukan penelitian responden diberikan informed consent dimana dalam inforned consent tersebut memberikan informasi mengenai tujuan, manfaat dan prosedur penelitian yang akan dilakukan kepada calon responden.

\section{Data Analysis}

Uji normalitas data menggunakan uji shapiro-wilk dan menggunakan uji skewnees dan kurtosis pada data yang tidak normal. Setelah normal dilakukan uji statistik repeated anova untuk menganalisis pengaruh akupresur 14 titik terhadap rentang gerak ekstremitas atas dan bawah. Selanjutnya untuk mengetahui kelompok mana yang paling signifikan digunakan uji post hoc bonferroni untuk repeated anova. Kesimpulan adanya pengaruh yang signifikan secara statistic digunakan tingkat kemaknaan $\alpha=0,05$ atau $\mathrm{p}<0,05.16$

\section{HASIL}

Tabel 1. Karakteristik responden berdasarkan usia, jenis kelamin dan frekuensi stroke pada kelompok intervensi dan kontrol di RSUD Kota Mataram, RSUD Provinsi NTB, RSUD Lobar, RSUD Loteng $(\mathrm{n}=38)$.

\begin{tabular}{|c|c|c|c|c|c|}
\hline \multirow[t]{3}{*}{ Variabel } & \multicolumn{4}{|c|}{ Kelompok Responden } & \multirow{3}{*}{$\begin{array}{c}\mathrm{P} \\
\text { Value } \\
\end{array}$} \\
\hline & \multicolumn{2}{|c|}{ Intervensi } & \multicolumn{2}{|c|}{ Kontrol } & \\
\hline & $\mathrm{N}$ & $\%$ & $\mathrm{~N}$ & $\%$ & \\
\hline Usia & 19 & & 19 & & 0.417 \\
\hline \multicolumn{6}{|l|}{$($ Mean \pm SD $)$} \\
\hline$-\quad 26-45$ & 1 & 5,3 & 1 & 5,3 & \\
\hline 46- 65 & 18 & 94,7 & 18 & 94,7 & \\
\hline Total & 19 & 100 & 19 & 100 & \\
\hline Jenis Kelamin & & & & & 1.000 \\
\hline - Laki-laki & 10 & 52,6 & 9 & 47,4 & \\
\hline - $\quad$ Perempuan & 9 & 47,4 & 10 & 52,6 & \\
\hline Total & 19 & 100 & 19 & 100 & \\
\hline Frekuensi & & & & & 1.000 \\
\hline \multicolumn{6}{|l|}{ Stroke } \\
\hline $\begin{array}{l}\text { - } \quad \text { Serangan } \\
\text { pertama }\end{array}$ & 10 & 52,6 & 9 & 47,4 & \\
\hline $\begin{array}{l}\text { - Serangan } \\
\text { kedua }\end{array}$ & 9 & 47,4 & 10 & 52,6 & \\
\hline Total & 19 & 100 & 19 & 100 & \\
\hline
\end{tabular}

Tabel 1 menunjukkan bahwa usia antara kelompok intervensi dan kontrol tidak berbeda ( $\mathrm{p}=0.417)$. Rata-rata usia kelompok intervensi dan kontrol berada pada rentang usia 46-65 (Lansia). Distribusi responden menurut jenis kelamin kedua kelompok tidak berbeda $(\mathrm{p}=1.000)$. Jumlah responden lakilaki dan perempuan sama banyak yaitu 19 orang perempuan dan 19 Orang laki-laki (100\%). Rata-rata frekuensi serangan stroke sama banyaknya antara kelompok intervensi dan kelompok control yaitu 19 orang pada frekuensi serangan pertama dan 19 orang 
pada serangan kedua (100\%).

Tabel 2. Analisis perbedaan rentang gerak ekstremitas atas sebelum dan Sesudah Perlakuan antara kelompok intervensi dan kelompok kontrol (Pairwise Comparisons) di RSUD Kota Mataram, RSUD Propinsi NTB, RSUD Lobar, RSUD Loteng $(n=38)$.

\begin{tabular}{|c|c|c|c|c|c|}
\hline $\begin{array}{c}\text { Kelompo } \\
\mathbf{k} \\
\text { responde } \\
\mathbf{n}\end{array}$ & $\begin{array}{l}\text { (I) } \\
\text { ses } \\
\text { i }\end{array}$ & $\begin{array}{c}(\mathbf{J}) \\
\operatorname{ses} \\
\mathbf{i}\end{array}$ & $\begin{array}{c}\text { Mean } \\
\text { Differenc } \\
\text { e }(\mathbf{I}-\mathbf{J})\end{array}$ & $\begin{array}{c}\text { Std. } \\
\text { Error }\end{array}$ & Sig. \\
\hline \multirow[t]{10}{*}{ Intervensi } & Pre & 7 & .000 & .186 & .000 \\
\hline & Pre & 1 & .000 & .000 & 1.00 \\
\hline & & & & & 0 \\
\hline & 1 & 2 & $-4.211^{*}$ & .620 & 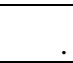 \\
\hline & 2 & 3 & $-7.368^{*}$ & .416 & .000 \\
\hline & 3 & 4 & $-7.362^{*}$ & .645 & .000 \\
\hline & 4 & 5 & $-8.421^{*}$ & .630 & .000 \\
\hline & 5 & 6 & $-6.842^{*}$ & .651 & .000 \\
\hline & 6 & 7 & $-34.474^{*}$ & 1.36 & .000 \\
\hline & & & & 5 & \\
\hline \multirow[t]{4}{*}{ Kontrol } & Pre & 7 & -.263 & .186 & .000 \\
\hline & Pre & 1 & .000 & .000 & \\
\hline & & & & & .166 \\
\hline & 1 & 2 & .000 & .620 & . \\
\hline
\end{tabular}

Tabel 2 diatas menunjukkan perbedaan waktu perbaikan rentang gerak ekstremitas atas sebelum dan sesudah perlakuan. Intervensi akupresur berpengaruh signifikan dalam memperbaiki rentang gerak ekstremitas atas pada hari 2 dengan hari 3 , hari 3 dengan hari 4 , hari 4 dengan hari 5 , hari 5 dengan hari 6 , hari 6 dengan hari 7 , dan pre intervensi dengan hari 7. Pada kelompok kontrol terlihat bahwa ada pengaruh yang signifikan pada hari 4 dengan hari 5, hari 5 dengan hari 6 , hari 6 dengan hari 7 , dan pre intervensi dengan hari 7 .

Tabel 3. Analisis Perbedaan rentang gerak ekstremitas atas Antara Kelompok Intervensi dan Kelompok Kontrol di RSUD Kota Mataram, RSUD Propinsi NTB, RSUD Lobar, RSUD Loteng $(n=38)$.

\begin{tabular}{cllll}
\hline \multicolumn{1}{c}{ Variabel } & Mean & SD & $\begin{array}{c}\text { P } \\
\text { Value }\end{array}$ \\
\hline $\begin{array}{c}\text { Rentang } \\
\text { gerak } \\
\text { ekstremi } \\
\text { tas atas }\end{array}$ & Kelompok & & & \\
\hline Pre & Intervensi & 30.53 & 7.05 & \multirow{2}{*}{1.000} \\
\cline { 2 - 4 } & Kontrol & 30.53 & 7.05 & \\
\hline Hari 1 & Intervensi & 30.53 & 7.05 & \multirow{2}{*}{.908} \\
\cline { 2 - 4 } & Kontrol & 30.79 & 6.92 & \\
\hline Hari 2 & Intervensi & 30.53 & 7.05 & \multirow{2}{*}{.908} \\
\cline { 2 - 4 } & Kontrol & 30.79 & 6.92 & \\
\hline Hari 3 & Intervensi & 34.74 & 8.58 & \multirow{2}{*}{.127} \\
\cline { 2 - 4 } & Kontrol & 30.79 & 6.92 & \\
\hline Hari 4 & Intervensi & 42.11 & 7.87 & .000 \\
\cline { 2 - 4 } & Kontrol & 30.79 & 6.92 & \\
\hline Hari 5 & Intervensi & 49.74 & 7.16 & \multirow{2}{*}{.000} \\
\cline { 2 - 4 } & Kontrol & 32.89 & 7.87 & \\
\hline Hari 6 & Intervensi & 58.16 & 6.91 & \multirow{2}{*}{.000} \\
\cline { 2 - 4 } & Kontrol & 40.53 & 7.62 & \\
\hline Hari 7 & Intervensi & 65.00 & 6.87 & \multirow{2}{*}{.000} \\
\cline { 2 - 4 } & Kontrol & 49.47 & 7.62 & \\
\hline
\end{tabular}

Tabel 3 diatas menunjukkan bahwa ada perbedaan yang bermakna antara perbaikan rentang gerak ekstremitas atas kelompok intervensi dengan kelompok kontrol pada hari ke 4, 5, 6, 7, $(\mathrm{p}=0.000$, $\mathrm{p}=0.000, \quad \mathrm{p}=0.000, \quad \mathrm{p}=0.000)$. Kedua kelompok sama-sama mengalami perbaikan rentang gerak ekstremitas atas. Walaupun demikian kelompok intervensi yang diberikan akupresur memiliki nilai perbaikan rentang gerak yang lebih tinggi dibandingkan dengan kelompok kontrol (mean 65,00). 
Tabel 4 Analisis Perbedaan rentang gerak ekstremitas bawah Antara Kelompok Intervensi dan Kelompok Kontrol di RSUD Kota Mataram, RSUD Propinsi NTB, RSUD LOBAR, RSUD LOTENG $(\mathrm{n}=38)$

\begin{tabular}{|c|c|c|c|c|}
\hline \multicolumn{2}{|c|}{ Variabel } & \multirow[t]{2}{*}{ Mean } & \multirow[t]{2}{*}{ SD } & \multirow{2}{*}{$\begin{array}{c}\mathbf{P} \\
\text { Value }\end{array}$} \\
\hline $\begin{array}{c}\text { Rentang } \\
\text { gerak } \\
\text { ekstremitas } \\
\text { bawah }\end{array}$ & Kelompok & & & \\
\hline \multirow[t]{2}{*}{ Pre } & Intervensi & 30.53 & 7.05 & 1.000 \\
\hline & Kontrol & 30.53 & 7.05 & \\
\hline \multirow[t]{2}{*}{ Hari 1} & Intervensi & 30.53 & 7.05 & .908 \\
\hline & Kontrol & 30.79 & 6.92 & \\
\hline \multirow[t]{2}{*}{ Hari 2} & Intervensi & 30.53 & 7.05 & .908 \\
\hline & Kontrol & 30.79 & 6.92 & \\
\hline \multirow[t]{2}{*}{ Hari 3} & Intervensi & 34.74 & 8.58 & .127 \\
\hline & Kontrol & 30.79 & 6.92 & \\
\hline \multirow[t]{2}{*}{ Hari 4} & Intervensi & 42.11 & 7.87 & .000 \\
\hline & Kontrol & 30.79 & 6.92 & \\
\hline \multirow[t]{2}{*}{ Hari 5} & Intervensi & 49.74 & 7.16 & .000 \\
\hline & Kontrol & 32.89 & 7.87 & \\
\hline \multirow[t]{2}{*}{ Hari 6} & Intervensi & 58.16 & 6.91 & .000 \\
\hline & Kontrol & 40.53 & 7.62 & \\
\hline \multirow[t]{2}{*}{ Hari 7} & Intervensi & 60.00 & 6.87 & .000 \\
\hline & Kontrol & 44.47 & 7.62 & \\
\hline
\end{tabular}

Tabel 4 diatas menunjukkan bahwa ada perbedaan yang bermakna antara perbaikan rentang gerak ekstremitas bawah kelompok intervensi dengan kelompok kontrol pada hari ke 4, 5, 6, 7, $(\mathrm{p}=0.000$, $\mathrm{p}=0.000, \quad \mathrm{p}=0.000, \quad \mathrm{p}=0.000)$. Kedua kelompok sama-sama mengalami perbaikan rentang gerak ekstremitas bawah. Walaupun demikian kelompok intervensi yang diberikan akupresur memiliki nilai perbaikan rentang gerak yang lebih tinggi dibandingkan dengan kelompok kontrol (mean 60,00).

\section{PEMBAHASAN}

Rata-rata usia mayoritas pada responden dallam penelitian ini adalah 4665 tahun sebanyak 38 orang pada kelompok intervensi dan kelompok kontrol. Hasil penelitian ini menunjukkan bahwa rerata usia pada kelompok kontrol lebih tinggi dibandingkan dengan kelompok intervensi, namun pada hasil analisis menunjukkan tidak ada perbedaan rerata yang bermakna antara usia kelompok intervensi dan kelompok control $(\mathrm{p}=0,417)$, sehingga dapat disimpulkan bahwa usia responden antara kelompok intervensi dan control setara atau homogen. Hal ini juga menunjukkan bahwa pengaruh usia responden terhadap perbaikan motorik pasien stroke non hemoragik telah dapat dikontrol.

Rerata usia dalam penelitian ini sejalan dengan temuan penelitian yang pernah dilakukan oleh Reny (2012) untuk mengidentifikasi pengaruh latihan ROM pada ekstremitas atas dengan bola karet terhadap kekuatan otot pasien stroke non hemoragik, didapati usia mayoritas responden yang mengidap penyakit stroke berkisar pada usia 45- 65 tahun.18 Hasil penelitian ini juga sejalan dengan hasil penelitian yang dilakukan oleh Nurul Atika (2013) untuk mengidentifikasi hubungan fisioterapi dengan peningkatan kemampuan fungsi motorik pada pasien stroke iskemik, dimana dalam penelitiannya diperoleh rerata usia mayoritas pasien stroke berkisar antara 56-65 tahun, pada usia lanjut terjadi proses kalsifikasi pembuluh darah, termasuk pembuluh darah otak. Usia merupakan faktor risiko stroke, semakin tua usia seseorang maka risiko terkena stroke pun semakin tinggi. Pasien stroke yang menginjak usia lansia juga akan mengalami keterbatasan fungsional yang lebih parah dibandingkan dengan pasien stroke yang usianya lebih muda. Semakin tua usia seseorang maka akan semakin lambat pula reorganisasi perfusi jaringan pada pembuluh darah diotak dikarenakan pembuluh darah diotak yang semakin mengeras (Atika, 2013).

Responden yang berjenis kelamin 
laki-laki dan perempuan pada penelitian ini jumlahnya sama banyak yaitu 19 orang lakilaki dan 19 orang perempuan pada kelompok intervensi dan kelompok kontrol. Hasil analisis menunjukkan bahwa tidak ada perbedaan proporsi jenis kelamin yang bermakna antara kelompok intervensi dan kelompok control $(\mathrm{p}=1,000)$. Hal ini juga menunjukkan bahwa pengaruh jenis kelamin responden terhadap perbaikan motorik ekstremitas atas dan bawah serta waktu perbaikan mototrik telah dapat dikontrol.

Temuan pada penelitian ini sejalan dengan hasil penelitian wayan dkk (2013) yang mengidentifikasi pengaruh akupresur scapula terhadap kekuatan otot ekstremitas atas pasien stroke non hemoragik, dimana dari 20 responden dalam penelitiannya, 10 orang berjenis kelamin laki-laki dan 10 orang berjenis kelamin perempuan.13 Penelitian ini juga mirip dengan penelitian yang telah dilakukan oleh Herin dan Farid (2012) untuk mengidentifikasi pengaruh latihan ROM pasif terhadap peningkatan kekuatan otot pada pasien stroke dengan hemiparese. Dari total 17 responden dalam penelitiannya, 9 orang berjenis kelamin lakilaki dan 8 orang berjenis kelamin perempuan (Mawarti H, 2012). Walaupun hasil penelitian ini menunjukkan jumlah responden yang sama banyaknya antara lakilaki dan perempuan, namun menurut Heart Disease and Stroke Statistic 2010, penderita stroke laki-laki 1,25 kali lebih banyak dibandingkan dengan perempuan dan sekitar 55.000 lebih perempuan dibandingkan lakilaki yang mengalami stroke setiap tahunnya (Fang J, 2012) Hal ini sangat mungkin terjadi karena ternyata stroke menyerang laki-laki pada usia yang lebih muda sehingga tingkat kelangsungan hidupnya lebih tinggi dan membuat angka kejadian stroke lebih banyak pada laki-laki. Selain itu perempuan terserang stroke pada usia yang lebih tua, sehingga lebih banyak wanita yang meninggal dibandingkan dengan laki-laki setiap tahunnya akibat stroke (Lewis, 2014)

Pada penelitian ini juga tampak adanya kecenderungan pada perempuan mengalami gangguan pada motorik yang lebih parah dibandingkan dengan laki-laki dan menunjukkan tingkat perbaikan yang lebih lambat dibandingkan dengan laki-laki. Turtzo dan McCullough (2008) mendukung fakta ini dengan mengemukakan bahwa jenis kelamin perempuan lebih banyak mengalami tingkat perbaikan motorik yang lebih rendah setelah terserang stroke dibandingkan dengan laki-laki, yaitu hanya sekitar 22,7\% perempuan pulih total dalam 6 bulan dibandingkan dengan laki-laki yang dapat pulih secara total sebanyak 26,7\% dalam 6 bulan sejak terserang stroke (Steven, 2008).

Temuan pada penelitian ini menunjukkan bahwa responden dengan stroke serangan pertama sama banyaknya dengan serangan kedua yaitu sebanyak 19 orang responden mengalami stroke serangan pertama dan 19 orang responden mengalami serangan stroke kedua baik pada kelompok intervensi maupun kelompok kontrol. Hasil analisis statistic menunjukkan bahwa tidak ada perbedaan yang bermakna antara kelompok intervensi dan kelompok control $(\mathrm{p}=1,000)$. Hal ini menunjukkan bahwa pengaruh frekuensi serangan stroke terhadap perbaikan motorik telah dapat dikontrol. Hasil penelitian ini sejalan dengan penelitian Nurul (2013) yang mengidentifikasi hubungan fisioterapi dengan peningkatan kemampuan fungsi motorik pada pasien stroke iskemik, dimana dari 38 responden terdapat 19 orang responden mengalami serangan stroke pertama dan 19 orang responden mengalami serangan stroke berulang (Atika, 2013). Walaupun hasil 
PROFESSIONAL HEALTH JOURNAL

Volume 2, No. 1, Desember 2020 (Hal. 51-63)

https://www.ojsstikesbanyuwangi.com/index.php/PHJ

penelitian ini menunjukkan jumlah responden yang sama banyak anatara serangan stroke pertama dan serangan stroke kedua, namun menurut Heart Disease and Stroke Statistic 2010, mengemukakan bahwa setiap tahunnya sekitar 750.000 orang mengalami stroke dimana sekitar 610.000 diantaranya merupakan serangan stroke pertama dan 140.000 merupakan serangan berulang (Fang, 2012).

Damush (2007) mengungkapkan bahwa pasien dengan serangan stroke yang berulang mengakibatkan kerusakan system neurologi yang lebih luas dibandingkan dengan orang yang baru terserang stroke yang pertama, sehingga orang dengan serangan stroke berulang membutuhkan waktu dan latihan yang lebih lama (Damush, 2007). Namun pada penelitian ini tidak terdapat perbedaan perbaikan motorik ekstremitas atas dan bawah yang bermakna antara responden dengan stroke serangan pertama dan serangan kedua. Ee Kwan dan Tan didalam Adam (2011) mendukung hal ini dengan temuan hasil penelitiannya yang menunjukkan bahwa pasien yang menderita stroke berulang tidak mengalami kerusakan fungsi fisik yang lebih parah jika dibandingkan dengan pasien stroke serangan pertama (Adam, 2011).

Dengan adanya perbedaan pendapat ini peneliti dapat menyimpulkan bahwa frekuensi serangan stroke mungkin saja dapat mempengaruhi tingkat keparahan pemulihan fungsi motorik pasien stroke, namun bukan merupakan factor penentu karena selain frekuensi stroke sendiri, terdapat beberapa factor-faktor pemulihan lain yang memiliki tingkat kontribusi yang berbeda-beda dalam mempengaruhi pemulihan pasien stroke, bahkan sangat mungkin factor-faktor tersebut tidak hanya terbatas pada aspek fisik saja, seperti yang dikemukakan oleh Ee Kwan dan Tan didalam Adam (2011) bahwa factor-faktor yang diketahui dapat menghambat proses pemulihan adalah gangguan memori, kurangnya motivasi untuk sembuh dan depresi (Adam, 2011).

\section{Perbedaan Rentang gerak ekstremitas atas Antara Kelompok Intervensi dan Kelompok Kontrol sebelum dan sesudah intervensi}

Dalam penelitian ini terdapat perbedaan yang bermakna antara perbaikan rentang gerak ekstremitas atas pada kelompok intervensi dibandingkan dengan kelompok control pada hari ke 4, 5, 6, dan 7 ( $\mathrm{p}=0,000, \mathrm{p}=0,000, \mathrm{p}=0,000, \mathrm{p}=0,000$ ). Kelompok yang diberikan akupresur memiliki peningkatan perbaikan rentang gerak ekstremitas atas yang lebih tinggi pada kelompok intervensi (mean 65,00) dibandingkan dengan kelompok control (mean 49,47). Pada kelompok intervensi diberikan akupresur stroke 14 titik selama 15 menit satu kali dalam sehari selama 7 hari dan menghasilkan perbaikan rentang gerak ekstremitas atas sebesar 53,03\%. Dalam penelitian ini juga dilihat effect size intervensi akupresur stroke 14 titik berpengaruh sebesar 5,93 (sangat kuat) terhadap rentang gerak ekstremitas atas pada pasien stroke non hemoragik. Hasil penelitian ini sejalan dengan penelitian yang telah dilakukan oleh Adam (2011) yang menyatakan bahwa setelah diberikan terapi akupresur selama 10 menit sekali dalam sehari selama 7 hari pada pasien stroke pasca rawat inap dapat memperbaiki rentang gerak ekstremitas atas sebesar 12,6\% (Fang, 2012).

Temuan pada penelitian ini sejalan dengan hasil penelitian sebelumnya yang dilakukan oleh Adam (2011) pada 34 pasien stroke pasca rawat inap. Pada kelompok 
intervensi setelah dilakukan akupresur dengan durasi 10 menit setiap hari selama 7 hari terjadi peningkatan rentang gerak ekstremitas atas pada rotasi eksterna bahu, fleksi bahu, abduksi bahu ekstensi siku dan supinasi lengan. Hasil temuan ini mendukung pemberian akupresur pada titik trigger pada ekstremitas atas dapat memperbaiki sirkulasi qi dan darah dalam tubuh, sehingga akan merelaksasikan otot yang mengeras dan merangsang perbaikan alamiah pada abnormalitas skeletal dan rentang gerak ekstremitas atas dapat meningkat. Selain itu, dikemukakan pula bahwa pemberian terapi akupresur akan mengharmonisasikan aliran qi dan darah sehingga akan merelaksasikan spasme dan meredakan nyeri pada sendi karena menstimulasi pelepasan endorphin (Fang, 2012)

Pada kelompok control diberikan latihan ROM pasif sesuai dengan protap dari rumah sakit untuk perawatan pasien stroke. Setelah diberikan latihan ROM pasif satu kali sehari dengan durasi 15 menit selama 7 hari mengalami peningkatan rentang gerak ekstremitas atas sebesar 38,29\%. Hal ini didukung oleh penelitian sebelumnya yang dilakukan oleh Reni (2011) yang menyatakan bahwa dengan diberikan latihan mobilisasi dini 3 kali sehari selama 7 hari dapat meningkatkan kemampuan fungsi motorik ekstremitas atas pada pasien hemiparese paska stroke iskemik. Menurut pendapat yang dikemukakan oleh Reni (2011) hal ini menunjukkan bahwa terapi latihan adalah salah satu cara yang mempercepat pemulihan pasien cedera dan penyakit yang dalam pelaksanaannya menggunakan gerakan-gerakan aktif maupun pasif. Latihan mobilisasi yang terdiri dari latihan rentang gerak sendi (ROM) dan ambulasi merupakan latihan peregangan proprioceptive neuromuscular facilitation (PNF) yang dapat kekuatan isometric dan isotonic. Latihan isotonic dapat meningkatkan tonus, massa dan kekuatan otot serta fleksibilitas persendian pada pasien hemiparese pasca stroke (Susan, 1996).

\section{Perbedaan Rentang Gerak ekstremitas bawah Antara Kelompok Intervensi dan Kelompok Kontrol sebelum dan sesudah intervensi}

Dalam penelitian ini terdapat perbedaan yang bermakna antara perbaikan rentang gerak ekstremitas bawah pada kelompok intervensi dibandingkan dengan kelompok control pada hari ke 4, 5, 6, dan 7 ( $\mathrm{p}=0,000, \mathrm{p}=0,000, \mathrm{p}=0,000, \mathrm{p}=0,000)$. Kelompok yang diberikan akupresur memiliki peningkatan perbaikan rentang gerak ekstremitas bawah yang lebih tinggi pada kelompok intervensi (mean 60,00) dibandingkan dengan kelompok control (mean 44,47). Pada kelompok intervensi diberikan akupresur stroke 14 titik selama 15 menit satu kali dalam sehari selama 7 hari dan menghasilkan perbaikan rentang gerak ekstremitas bawah sebesar 49,12\%. Dalam penelitian ini juga dilihat effect size intervensi akupresur stroke 14 titik berpengaruh sebesar 5,93 (sangat kuat) terhadap rentang gerak ekstremitas bawah pada pasien stroke non hemoragik. Hasil penelitian ini di dukung dengan penelitian yang telah dilakukan oleh Kang Et Al (2008) yang menyatakan bahwa setelah diberikan terapi akupresur pada titik meridian selama 10 menit sekali dalam sehari selama 14 hari pada pasien stroke pasca rawat inap dapat meningkat kan ADL sebesar 25,44\% (Mawarti, 2012).

Dengan adanya hasil penelitian ini dan juga hasil penelitian sebelumnya, 
peneliti dapat berkesimpulan bahwa pemberian terapi akupresur pada titik trigger pada ekstremitas bawah dapat meningkatkan rentang gerak ekstremitas bawah secara bermakna pada pasien stroke. Titik trigger merupakan titik sensitif yang bila di tekan akan menimbulkan nyeri pada tempat yang jauh dari titik tersebut, dimana titik ini merupakan degenerasi lokal di dalam jaringan otot yang dapat di sebabkan oleh spasme otot, trauma, ketidakseimbangan endokrin dan ketidakseimbangan otot. Titik trigger dapat ditemukan pada otot rangka dan tendon, ligament, kapsul sendi, periosteum dan kulit. Otot yang normal tidak mempunyai titik trigger. Pemberian terapi akupresur akan mengharmonisasikan aliran qi dan darah sehingga akan merelaksasikan spasme dan meredakan nyeri pada sendi karena menstimulasi pelepasan endorphin, sehingga akan merelaksasikan otot yang mengeras dan merangsang perbaikan alamiah pada abnormalitas skeletal dan rentang gerak ekstremitas bawah dapat meningkat (Mawarti, 2012).

Pada kelompok control diberikan latihan ROM pasif sesuai dengan protap dari rumah sakit untuk perawatan pasien stroke. Setelah diberikan latihan ROM pasif satu kali sehari dengan durasi 15 menit selama 7 hari mengalami peningkatan rentang gerak ekstremitas bawah sebesar 31,34\%. Hal ini didukung oleh penelitian sebelumnya yang dilakukan oleh Reni (2011) yang menyatakan bahwa dengan diberikan latihan mobilisasi dini 3 kali sehari selama 7 hari dapat meningkatkan kemampuan fungsi motorik pada pasien hemiparese paska stroke iskemik. Menurut pendapat yang dikemukakan oleh Reni (2011) hal ini menunjukkan bahwa terapi latihan adalah salah satu cara yang mempercepat pemulihan pasien cedera dan penyakit yang dalam pelaksanaannya menggunakan gerakangerakan aktif maupun pasif. Latihan mobilisasi yang terdiri dari latihan rentang gerak sendi (ROM) dan ambulasi merupakan latihan peregangan proprioceptive neuromuscular facilitation (PNF) yang dapat kekuatan isometric dan isotonic. Latihan isotonic dapat meningkatkan tonus, massa dan kekuatan otot serta fleksibilitas persendian pada pasien hemiparese pasca stroke (Susan, 1996).

\section{KESIMPULAN}

Akupresur 14 titik efektif untuk meningkatkan rentang gerak ekstremitas atas dan bawah pada pasien stroke non hemoragik. Bagi perawat di ruang stroke senter untuk menerapkan akupresur 14 titik sebagai salah satu SOP atau protap dalam perawatan pasien stroke non hemoragik untuk meningkatkan rentang gerak ekstremitas. Bagi perawat di ruang stroke center sebaiknya mengikuti pelatihan akupresur yang telah tersertifikasi dan menjadikan terapi akupresur sebagai salah satu keahlian atau kompetensi yang dimiliki untuk di terapkan pada pemberian asuhan keperawatan pada pasien stroke. Bagi penelitian selanjutnya perlu menambahkan durasi pemberian akupresur dan memodifikasi atau menambahkan titik akupresur sehingga terjadi pemulihan rentang gerak pada pasien stroke non hemoragik, dan perlu meneliti aspek lain yang mempengaruhi pemulihan motorik pada pasien stroke seperti usia dan frekuensi stroke. 


\section{DAFTAR PUSTAKA}

Mansjoer A. (2000). Kapita Selekta Kedokteran, Edisi 3. Jakarta: Media Aesculapius FKUI.

Mansjoer A. (2010). Kapita Selekta Kedokteran, Edisi 4. Jakarta: Media Aesculapius FKUI.

Muttaqin A. (2011). Asuhan Keperawatan Klien dengan Gangguan Sistem Persarafan. Jakarta: Salemba Medika.

Wiwit. (2010) Stroke dan Penanganannya. Yogyakarta: Kata Hati.

Atika N. (2013). Hubungan Fisioterapi dengan Peningkatan Kemampuan Fungsi Motorik pada Pasien Stroke Iskemik di Rumah Sakit PKU Muhammadiyah Surakarta. Surakarta: Universitas Muhammadiyah Surakarta.

Black JM, Hawks JH. (2009). MedicalSurgical Nursing: Saunders/Elsevier.

LeMone P, Burke KM. (2008). Clinical Handbook for Medical-Surgical Nursing: Critical Thinking in Client Care: Prentice Hall.

Saputra K, Sudirman S. (2009). Akupuntur untuk Nyeri dengan Pendekatan Neurosain. Jakarta: CV. Sagung Seto.

Si Q-m, Wu G-c, Cao X-d. (1998). Effects of Electroacupuncture on Acute Cerebral Infarction. Acupuncture \& ElectroTherapeutics Research; 23 (2): 117-24.

Shin B-C, Lee MS. (2007). Effects of Aromatherapy Acupressure on Hemiplegic Shoulder Pain and Motor Power in Stroke Patients: A Pilot Study. The Journal of Alternative and Complementary Medicine; 13 (2): 24752.
Kang HS, Sok SR, Kang JS. (2009). Effects of Meridian acupressure for stroke patients in Korea. Journal of Clinical Nursing; 18 (15): 2145-52.

Adam M. (2011). Pengaruh Akupresur Terhadap Kekuatan Otot dan Rentang Gerak Ekstremitas Atas Pada Pasien Stroke Pasca Rawat Inap di RSUP Fatmawati. Jakarta. Melalui: http://lontar ui ac id/file.

Sukwana IW, Sukarja IM, Diputra IKW. (2013). Akupresur Scapula Terhadap Kekuatan Otot Ekstremitas Pasien Stroke Non Hemoragik. E-Jounal Poltekkes Denpasar

Butcher HK, Bulechek GM, Dochterman JMM, Wagner C. (2013). Nursing Interventions Classification (NIC): Elsevier Health Sciences.

Dupler, Douglas. (2005). Gale Encyclopedia of Alternative Medicine Acupressure. diakses melalui http://wwwencyclopediacom/topic/acup ressureaspx.

Mawarti H. (2012). Pengaruh Latihan Rom (Range Of Motion) Pasif terhadap Peningkatan Kekuatan Otot pada Pasien Stroke dengan Hemiparase. Eduhealth;2 (2)

Fang J, Shaw KM, George MG. (2012). Prevalence of Stroke-United States, 2006-2010 (Reprinted form Mmwr, Vol 61, Pg 379, 2012). Amer Medical Assoc 515 N State St, Chicago, Il 60654-0946 Usa; P. 228-30.

Lewis SL, Dirksen SR, Heitkemper MM, Bucher L. (2014). Medical-Surgical Nursing: Assessment and Management of Clinical Problems, Single Volume: Elsevier Health Sciences. 
PROFESSIONAL HEALTH JOURNAL

Volume 2, No. 1, Desember 2020 (Hal. 51-63)

https://www.ojsstikesbanyuwangi.com/index.php/PHJ

Steven S. (2008). Hubungan

Derajat Spastisitas Maksimal Berdasarkan Modified Ashworth Scale dengan Gangguan Fungsi Berjalan pada Penderita Stroke Iskemik. Semarang: Diponegoro University.

Damush TM, Plue L, Bakas T, Schmid A, Williams LS. (2007). Barriers and Facilitators to Exercise among Stroke Survivors. Rehabilitation Nursing; 32 (6): 253-62.

Suharningsih. (1999). Profil Tegangan Listrik Titik Akupuntur sebagai Indikator Kelainan Biofisika. Surabaya: Program Pascasarjana Universitas Airlangga.

Susan. (1996). Physiologi for Nursing Practice: 2nd ed. London: Philadelphia Toronto Sydney. 